\title{
Declare Malayan Tiger Killers 'Enemies-of-the-State'
}

\author{
Muhd Nur Iman Ramli*
}

A country's national symbol serves as a tool of unity. People express their passion, patriotism, aspirations, and inspiration via a national symbol, which helps define the nation's identity. Animals of pride, such as the eagle in the United States, the lion in the United Kingdom, the brown bear in Russia, and the komodo dragon in Indonesia, have long been revered as symbols of a country's grandeur. The Malayan tiger (panthera tigris jacksoni) is a symbolic animal in Malaysia, representing the Malaysian people's strength, determination, and courage.

The Malayan tiger is Malaysia's National Emblem (Jata Negara) and appears on the official coat-of-arm of the Yang di-Pertuan Agong. The image of the Malayan tiger's head also appears on the logos of the Royal Malaysian Police Force (PDRM); Malaysia's first national car, PROTON; the country's leading bank, Maybank; and the country's renowned football club, Johor Darul Ta'zim (JDT). 'Harimau Malaya' is also the national football team's nickname.

Except for the Department of Wildlife and National Parks (PERHILITAN) and non-governmental organisations (NGOs) such as World Wildlife Fund (WWF) and MyCat, which are working to save Malayan tigers from extinction, Malaysians have paid little attention to the lives or deaths of Malayan tigers in the forest.

While the numbers of Malaysian tigers is rapidly declining, World Tiger Day was observed on July 29, 2021. Harimau Malaya is a tiger subspecies found solely in Peninsular Malaysia, particularly in Kelantan, Perak, Pahang, and Terengganu. In comparison to 3,000 tigers recorded in national forests in the 1950s, the 1st National Tiger Survey (NTS) from 2016 to 2018 revealed that the number of Malayan tigers has now drastically reduced to just 200! If this is not taken seriously, the nation will lose this species altogether in the next five to ten years.

The major factor affecting Malayan tigers' food sources, habitats, and breeding grounds has been forest degradation for development and logging. Illegal poaching has also proven destructive. Surprisingly, even though Malayan tigers are symbolic Malaysian creatures listed as fully protected species under the Wildlife Conservation Act 2010 (Act 716), neither local nor international poachers are deterred from killing them. 
Poachers sneak into forests and set traps. Slain Malayan tigers are then used for their skin, claws, fangs, bones, and flesh. Consuming or exploiting tiger body parts for commercial purposes is an atrocious act of cruelty. The high demand for them on the black-market motivates poachers to kill more tigers to maximise profits, rather than consider the devastation to ecosystems, much less the extinction of species, that could result from their reckless acts.

Apart from the 'Ops Bersatu Khazanah' special operation between PERHILITAN and PDRM, there should be more attempts to recognise Malayan tigers as part of Malaysia's national heritage. Killers of Malayan tigers should be considered 'enemies-of-the-state' and severely punished for killing such a symbolic animal, an act as heinous as burning the Jalur Gemilang, ridiculing the national anthem, or desecrating the National Emblem. Special operations to arrest poachers should be carried out on a regular basis.

HRH the Sultan of Johor, Sultan Ibrahim Ibni Almarhum Sultan Iskandar, issued a harsh warning against Malayan tiger poachers in October 2019: "Poachers will be hunted" if they continue to kill Malayan tigers in Johor. Perhaps now is the appropriate time for the palace to pay attention to and actively intervene in the plight of Malayan tigers in the wild.

At the grassroots level, the struggle against poachers and the campaign to save Malayan tigers needs patriotism from all parties, corporate entities, and the country's leadership.

From an Islamic point of view, the act of abusing or killing animals for reasons other than those authorised by law, religion, or morality is against Islamic principles. Therefore, any noble efforts to save animals, especially endangered species, are in accordance with Islamic teaching.

Among the ongoing initiatives to save Malayan tigers is the RM20.8 million establishment of the National Tiger Conservation Centre (NTCC) in Kampung Bolok Hulu, Lanchang, Pahang. Its primary goals are to perform research into the enrichment of the Malayan tigers' habitat and food resources, as well as breeding programmes to boost the population.

Three of the nine Malayan tiger subspecies are now extinct. If no substantial measures are taken, we may lose the Malayan tigers for good in less than a decade. Poaching and illicit trading have caused the extinction of Bali and Javanese tigers in Indonesia. Certainly, there is no hope of resurrecting an extinct species.

\section{Notes}

* Muhd Nur Iman Ramli is the Conference Executive at the International Institute of Advanced Islamic Studies (IAIS) Malaysia. He can be contacted at: iman@ iais.org.my. 